\title{
Role of echocardiography for silent cerebrovascular disease
}

\author{
Kenji Matsumoto, Marco R Di Tullio and Shunichi Homma* \\ Department of Medicine, Columbia University, New York, USA
}

\begin{abstract}
Silent cerebrovascular disease, such as silent brain infarctions and white matter hyperintensities detected on magnetic resonance imaging is frequently observed in the elderly and carries an increased risk of future stroke and dementia. Echocardiography is a widely available and relatively inexpensive imaging modality for the detection of cardioembolic sources. In addition, the associations of abnormal echocardiographic findings with cognitive impairment have been recently shown. Therefore, to understand the association between cardiac abnormalities assessed by echocardiography and silent cerebrovascular disease may provide a cost-effective opportunity to detect abnormalities that may affect the risk of future adverse events, with potential preventative implications. In the present mini review, we highlight the role of echocardiography in silent cerebrovascular disease.
\end{abstract}

\section{Introduction}

Silent cerebrovascular disease (SCD), such as silent brain infarctions (SBI) and white matter hyperintensities (WMH) on magnetic resonance imaging, is frequently observed in elderly [1]. Although often called silent, because it occurs in the absence of clinically apparent neurological symptoms, SCD carries an increased risk of future stroke [2,3] and dementia [4]. As conditions associated with poor brain health represent leading causes of global morbidity and mortality [5], identifying individuals at increased risk of SCD may allow for early and more effective prevention strategies. Echocardiography [both transthoracic (TTE) and transesophageal (TEE)] is a widely available, relatively inexpensive and non-invasive imaging modality that can play an important role for the detection of cardioembolic source for stroke [6]. In addition, the associations of abnormal echocardiographic findings with cognitive impairment have been recently shown [7]. Therefore, to understand the association between cardiac abnormalities assessed by echocardiography and SCD may provide cost-effective opportunities to detect abnormalities that may be acted on to try and decrease the risk of future adverse events.

\section{Left ventricular parameters and silent cerebrovascular disease}

\section{Left ventricular systolic function}

Decreased cerebral blood flow subsequent to low cardiac output [8] and formation of left ventricular (LV) thrombus [9] are two potential pathophysiologic mechanisms accounting for SCD in patients with severe systolic heart failure (HF). Previous studies showed that a low LV ejection fraction was independently related to the presence of SCD in HF $[10,11]$. However, this relationship was not clearly observed in community-based participants whose LV ejection fraction was within the normal range [12-14]. Recently, Russo et al. [14] have shown that the early LV systolic dysfunction detected by lower global longitudinal strain, but not LV ejection fraction, was associated with the presence of SCD. Lower global longitudinal strain, which appears insufficient to result in both significant reduction in cerebral perfusion or be a source of thrombus formation and embolism, might in fact be a sensitive indicator of generalized atherosclerosis [15].

\section{Left ventricular diastolic function}

LV diastolic dysfunction evaluated by transmitral flow velocity and mitral annular tissue Doppler velocity is associated with the presence of SBI $[13,16]$ and WMH $[17,18]$ in community-based studies. The possible mechanism underlying the relationship between diastolic dysfunction and SCD may be multifocal. The early diastolic dysfunction may reflect generalized changes in the vascular system, which could contribute to subclinical atherosclerosis including endothelial dysfunction $[13,19]$. Moreover, the reduced systemic perfusion and thus impairment of the autoregulation of cerebral blood flow that may occur in LV diastolic dysfunction may affect the progression of WMH [17,20]. On the other hand, an association between LV diastolic dysfunction and SBI was also shown in patients with non-valvular atrial fibrillation [21] and HF [10]. In the advanced diastolic dysfunction observed in those patients, the elevated diastolic filling pressure may lead to blood stasis associated with spontaneous echo contrast and left atrial thrombus formation, which are known risk factors for embolic events [10,22]. Ishikawa et al showed that poor LV diastolic function assessed by TTE was significantly associated with a high prevalence of those left atrial (LA) abnormalities detected by TEE [21].

\section{Left ventricular mass}

Increased LV mass (LVM), particularly in the case of concentric LV hypertrophy (LVH), appears to be associated with the presence of SCD. LVM is a possible clinical marker of end-organ damage in the cerebral vasculature, as it provides a time-integrated summation of exposure to various cardiovascular risk factors [23-25]. Recently, Johansen et al found that greater LVM index was associated with the presence of SCD in a large community-based study [12]. Similar results were shown in

${ }^{\star}$ Correspondence to: Shunichi Homma, Division of Cardiology, Columbia University Medical Center, PH 3-342, 622 West 168th Street, New York, NY 10032, USA, Tel: +121-230-530-68; Fax: +1-212 3059049; E-mail: sh23@cumc. columbia.edu

Key words: silent cerebrovascular disease, echocardiography, silent brain infarction Received: May 01, 2019; Accepted: May 10, 2019; Published: May 13, 2019 
several cross-sectional studies [13,26,27]. Furthermore, the association between LV geometric patterns and the prevalence of SCD has been also investigated [28-30]. Nakanishi et al showed that concentric LVH carried the greatest independent risk for both SBI and WMH, followed by eccentric $\mathrm{LVH}$, whereas concentric remodelling was not associated with SCD in the large cohort [29]. On the other hand, Haring et al recently demonstrated that higher LVM in midlife was associated with greater severity of $\mathrm{WMH}$ in later life [23]. Overall, it can be said that current evidence supports a strong relationship between LV mass and the presence of SCD.

\section{Left atrial parameters and silent cerebrovascular disease}

Several studies showed that LA enlargement is associated with both SBI [31] and WMH [32]. Recently, Russo et al. [33] demonstrated that greater LA volumes and smaller LA reservoir function assessed by realtime three-dimensional echocardiography were associated with SCD in a community-based cohort. Poor LA function can be an expression of long-standing hypertension, LVH, LV diastolic dysfunction and increased filling pressure which may lead to reduce cerebral perfusion [34] and is therefore considered as a powerful marker of cardiovascular diseases [35]. In addition, due to the strong association between increased LA size and incident atrial fibrillation [36], cardioembolism may be the other possible mechanism linking LA dysfunction and SCD. On the other hand, Sugioka et al found that LA abnormalities such as LA thrombus, spontaneous echo contrast and LA appendage emptying velocity, known risk factors for embolic stroke assessed by TEE, were associated with the presence of SBI in patients with atrial fibrillation [37].

\section{Aortic atherosclerosis and silent cerebrovascular disease}

Complex aortic arch plaques (AAP) are considered an important source of thromboembolism and ischemic stroke in the elderly [38]. Accordingly, the association between complex AAP detected by TEE and SBI were shown in patients with atrial fibrillation [37] and HF [10]. Recently, Tugcu et al. [39] showed an association of AAP assessed by TTE with WMH in a large community-based cohort. The presence of AAP, strongly associated with arterial stiffness [40], may be also considered as a marker of diffuse and subclinical atherosclerosis.

\section{Other findings}

Rodriguez et al. [41] showed an association between left-sided annular or valvular calcification and SCD in a large community-based elderly cohort, although it is still unknown whether such abnormalities are just markers of subclinical atherosclerosis [42,43]. Finally, Di Tullio et al. [44] reported that patent foramen ovale was not associated with SCD as well as future stroke in the general population.

\section{Conclusions}

Although the precise underlying mechanisms are unclear, current evidence shows that various cardiac abnormalities detected by echocardiography are associated with the presence of SCD. Therefore, primary prevention strategies resulting in reduced vascular risk-factors may concurrently improve both heart and brain health. Further prospective investigations are needed to refine the role of echocardiography for SCD in clinical settings.

\section{References}

1. Smith EE, Saposnik G, Biessels GJ, Doubal FN, Fornage M, et al. (2017) Prevention of Stroke in Patients With Silent Cerebrovascular Disease: A Scientific Statement for Healthcare Professionals From the American Heart Association/American Stroke Association. Stroke 48: e44-e71. [Crossref]

2. Kuller LH, Longstreth WT Jr, Arnold AM, Bernick C, Bryan RN, et al. (2004) White matter hyperintensity on cranial magnetic resonance imaging: a predictor of stroke. Stroke 35: 1821-1825. [Crossref]

3. Vermeer SE, Hollander M, van Dijk EJ, Hofman A, Koudstaal PJ, et al. (2003) Silent brain infarcts and white matter lesions increase stroke risk in the general population: the Rotterdam Scan Study. Stroke 34: 1126-1129. [Crossref]

4. Debette S, Beiser A, DeCarli C, Au R, Himali JJ, et al. (2010) Association of MRI markers of vascular brain injury with incident stroke, mild cognitive impairment, dementia, and mortality: the Framingham Offspring Study. Stroke 41: 600-606. [Crossref]

5. Gardener H, Wright CB, Rundek T, Sacco RL (2015) Brain health and shared risk factors for dementia and stroke. Nat Rev Neurol 11: 651-657. [Crossref]

6. Nakanishi K, Homma S (2016) Role of echocardiography in patients with stroke. $J$ Cardiol 68: 91-99. [Crossref]

7. Arangalage D, Ederhy S, Dufour L, Joffre J, Van der Vynckt C, et al. (2015) Relationship between cognitive impairment and echocardiographic parameters: a review. J Am Soc Echocardiogr 28: 264-274. [Crossref]

8. Alosco ML, Brickman AM, Spitznagel MB, Garcia SL, Narkhede A, et al. (2013) Cerebral perfusion is associated with white matter hyperintensities in older adults with heart failure. Congest Heart Fail 19: E29-34. [Crossref]

9. Lip GY, Gibbs CR (1999) Does heart failure confer a hypercoagulable state? Virchow's triad revisited. J Am Coll Cardiol 33: 1424-1426. [Crossref]

10. Kozdag G, Ciftci E, Vural A, Selekler M, Sahin T, et al. (2006) Silent cerebral infarction in patients with dilated cardiomyopathy: echocardiographic correlates. Int $J$ Cardiol 107: 376-381. [Crossref]

11. Vogels RL, van der Flier WM, van Harten B, Gouw AA, Scheltens P, et al. (2007) Brain magnetic resonance imaging abnormalities in patients with heart failure. Eur $J$ Heart Fail 9: 1003-1009. [Crossref]

12. Johansen MC, Shah AM, Lirette ST, Griswold M, Mosley TH, et al. (2018) Associations of Echocardiography Markers and Vascular Brain Lesions: The ARIC Study. $J \mathrm{Am}$ Heart Assoc 7: e008992. [Crossref]

13. McAreavey D, Vidal JS, Aspelund T, Owens DS, Hughes T, et al. (2010) Correlation of echocardiographic findings with cerebral infarction in elderly adults: the AGESReykjavik study. Stroke 41: 2223-2228. [Crossref]

14. Russo C, Jin Z, Homma S, Elkind MS, Rundek T, et al. (2013) Subclinical left ventricular dysfunction and silent cerebrovascular disease: the Cardiovascular Abnormalities and Brain Lesions (CABL) study. Circulation 128: 1105-1111. [Crossref]

15. Laurent S, Briet M, Boutouyrie P (2009) Large and small artery cross-talk and recent morbidity-mortality trials in hypertension. Hypertension 54: 388-392. [Crossref]

16. de Bruijn RF, Portegies ML, Leening MJ, Bos MJ, Hofman A, et al. (2015) Subclinical cardiac dysfunction increases the risk of stroke and dementia: the Rotterdam Study. Neurology 84: 833-840. [Crossref]

17. Shimizu A, Sakurai T, Mitsui T, Miyagi M, Nomoto K, et al. (2014) Left ventricular diastolic dysfunction is associated with cerebral white matter lesions (leukoaraiosis) in elderly patients without ischemic heart disease and stroke. Geriatr Gerontol Int 14 Suppl 2: 71-76. [Crossref]

18. Masugata H, Senda S, Goda F, Yamagami A, Okuyama H, et al. (2008) Cardiac diastolic dysfunction is associated with cerebral white matter lesions in elderly patients with risk factors for atherosclerosis. Tohoku J Exp Med 216: 99-108. [Crossref]

19. Guazzi M, Arena R (2009) Endothelial dysfunction and pathophysiological correlates in atrial fibrillation. Heart 95: 102-106. [Crossref]

20. Jefferson AL (2010) Cardiac output as a potential risk factor for abnormal brain aging. J Alzheimers Dis 20: 813-821. [Crossref]

21. Ishikawa S, Sugioka K, Sakamoto S, Fujita S, Ito A, et al. (2017) Relationship between tissue Doppler measurements of left ventricular diastolic function and silent brain infarction in patients with non-valvular atrial fibrillation. Eur Heart $J$ Cardiovasc Imaging 18: 1245-1252. [Crossref] 
22. Doukky R, Garcia-Sayan E, Patel M, Pant R, Wassouf M, et al. (2016) Impact of diastolic function parameters on the risk for left atrial appendage thrombus in patients with nonvalvular atrial fibrillation: a prospective study. J Am Soc Echocardiogr 29: 545-553. [Crossref]

23. Haring B, Omidpanah A, Suchy-Dicey AM, Best LG, Verney SP, et al. (2017) Left Ventricular Mass, Brain Magnetic Resonance Imaging, and Cognitive Performance: Results From the Strong Heart Study. Hypertension 70: 964-971. [Crossref]

24. Levy D, Garrison RJ, Savage DD, Kannel WB, Castelli WP (1990) Prognostic implications of echocardiographically determined left ventricular mass in the Framingham Heart Study. N Engl J Med 322: 1561-1566. [Crossref]

25. Levy D, Anderson KM, Savage DD, Kannel WB, Christiansen JC, et al. (1988) Echocardiographically detected left ventricular hypertrophy: prevalence and risk factors: the Framingham Heart Study. Ann Intern Med 108: 7-13. [Crossref]

26. Henskens LH, van Oostenbrugge RJ, Kroon AA, Hofman PA, Lodder J, et al. (2009) Detection of silent cerebrovascular disease refines risk stratification of hypertensive patients. J Hypertens 27: 846-853. [Crossref]

27. Fox ER, Taylor HA Jr, Benjamin EJ, Ding J, Liebson PR, et al. (2005) Left ventricular mass indexed to height and prevalent MRI cerebrovascular disease in an African American cohort: the Atherosclerotic Risk in Communities study. Stroke 36: 546-550. [Crossref]

28. Selvetella G, Notte A, Maffei A, Calistri V, Scamardella V, et al. (2003) Left ventricular hypertrophy is associated with asymptomatic cerebral damage in hypertensive patients. Stroke 3: 1766-1770. [Crossref]

29. Nakanishi K, Jin Z, Homma S, Elkind MS, Rundek T, et al. (2017) Left ventricular mass-geometry and silent cerebrovascular disease: The Cardiovascular Abnormalities and Brain Lesions (CABL) study. Am Heart $J$ 185: 85-92. [Crossref]

30. Kohara K, Zhao B, Jiang Y, Takata Y, Fukuoka T, et al. (1999) Relation of left ventricular hypertrophy and geometry to asymptomatic cerebrovascular damage in essential hypertension. Am J Cardiol 83: 367-370. [Crossref]

31. Cogswell RJ, Norby FL, Gottesman RF, Chen LY, Solomon S, et al. (2017) High prevalence of subclinical cerebral infarction in patients with heart failure with preserved ejection fraction. Eur J Heart Fail 19: 1303-1309. [Crossref]

32. Oh JE, Shin JW, Sohn EH, Jung JO, Jeong SH, et al. (2012) Effect of cardiac function on cognition and brain structural changes in dementia. J Clin Neurol 8: 123-129. [Crossref]
33. Russo C, Jin Z, Liu R, Iwata S, Tugcu A, et al. (2013) LA volumes and reservoir function are associated with subclinical cerebrovascular disease: the CABL (Cardiovascular Abnormalities and Brain Lesions) study. JACC Cardiovasc Imaging 6: 313-323. [Crossref]

34. Abhayaratna WP, Seward JB, Appleton CP, Douglas PS, Oh JK, et al. (2006) Left atrial size: physiologic determinants and clinical applications. J Am Coll Cardiol 47: 2357-2363. [Crossref]

35. Benjamin EJ, D'Agostino RB, Belanger AJ, Wolf PA, Levy D (1995) Left atrial size and the risk of stroke and death. The Framingham Heart Study. Circulation 92: 835841. [Crossref]

36. Cozma D, Popescu BA, Lighezan D, Lucian P, Mornos C, et al. (2007) Left atria remodeling: assessment of size and shape to detect vulnerability to atrial fibrillation. Pacing Clin Electrophysiol 30 Suppl 1: S147-150. [Crossref]

37. Sugioka K, Takagi M, Sakamoto S, Fujita S, Ito A, et al. (2015) Predictors of silent brain infarction on magnetic resonance imaging in patients with nonvalvular atrial fibrillation: A transesophageal echocardiographic study. Am Heart J 169: 783-790. [Crossref]

38. Kronzon I, Tunick PA (2006) Aortic atherosclerotic disease and stroke. Circulation 114: 63-75. [Crossref]

39. Tugcu A, Jin Z, Homma S, Elkind MS, Rundek T, et al. (2016) Atherosclerotic Plaques in the Aortic Arch and Subclinical Cerebrovascular Disease. Stroke 47: 2813-2819. [Crossref]

40. van Popele NM, Grobbee DE, Bots ML, Asmar R, Topouchian J, et al. (2001) Association between arterial stiffness and atherosclerosis: the Rotterdam Study. Stroke 32: 454-460. [Crossref]

41. Rodriguez CJ, Bartz TM, Longstreth WT Jr, Kizer JR, Barasch E, et al. (2011) Association of annular calcification and aortic valve sclerosis with brain findings on magnetic resonance imaging in community dwelling older adults: the cardiovascular health study. J Am Coll Cardiol 57: 2172-2180. [Crossref]

42. Abramowitz Y, Jilaihawi H, Chakravarty T, Mack MJ, Makkar RR (2015) Mitral Annulus Calcification. J Am Coll Cardiol 66: 1934-1941. [Crossref]

43. Adler Y, Levinger U, Koren A, Tanne D, Fink N, et al. (2000) Relation of nonobstructive aortic valve calcium to carotid arterial atherosclerosis. Am J Cardiol 86: 1102-1105. [Crossref]

44. Di Tullio MR, Jin Z, Russo C, Elkind MS, Rundek T, et al. (2013) Patent foramen ovale, subclinical cerebrovascular disease, and ischemic stroke in a population-based cohort. J Am Coll Cardiol 62: 35-41. [Crossref]

Copyright: (C2019 Matsumoto K. This is an open-access article distributed under the terms of the Creative Commons Attribution License, which permits unrestricted use, distribution, and reproduction in any medium, provided the original author and source are credited. 